\title{
PENGARUH DUA JENIS PAKAN TERHADAP LAMA STADIUM LARVA KUMBANG Tenebrio molitor (COLEOPTERA: TENEBRIONIDAE)
}

\section{THE EFFECT OF TWO KINDS OF FOOD TO THE LONGEVITY OF Tenebrio molitor LARVAE (COLEOPTERA: TENEBRIONIDAE)}

\author{
Rahmawati, Nismah Nukmal, Suratman Umar \\ Jurusan Biologi FMIPA Universitas Lampung \\ JI. Prof. Dr. Soemantri Brodjonegoro No. 1 Bandar Lampung 35145 \\ e-mail: nismah.nukmal@fmipa.unila.ac.id
}

\begin{abstract}
ABSTRAK
Tenebrio molitor merupakan serangga yang memiliki nilai ekonomis dan mudah dipelihara. Pemberian pakan yang tepat dapat meningkatkan pertumbuhan dan reproduksi dari T. molitor. Ragi merupakan pakan utama $T$. molitor yang dapat meningkatkan proses pencernaannya sehingga pertumbuhan dapat mencapai optimal. Sedangkan styrofoam merupakan bahan polistiren yang dapat menjadi pakan alternatif bagi T. molitor. Tujuan penelitian ini adalah untuk mengetahui pengaruh dua jenis pakan (ragi dan styrofoam) terhadap lama stadium larva kumbang $T$. molitor. Metode yang digunakan dalam penelitian ini adalah metode eksperimen skala laboratorium menggunakan Rancangan Acak Kelompok dengan 10 kali pengulangan. Parameter yang diamati dalam penelitian adalah panjang larva, berat larva, lama stadium larva, dan berat pakan yang dimakan. Data yang diperoleh dari penelitian selanjutnya dianalisis dengan uji T. Hasil penelitian menunjukkan bahwa perbedaan pakan mempengaruhi berat larva, panjang larva, dan lama stadium larva $(p<0,05)$. Larva $T$. molitor yang diberi pakan ragi lebih singkat stadiumnya dibandingkan dengan yang diberi pakan styrofoam.
\end{abstract}

Kata kunci : Tenebrio molitor, ragi, styrofoam, stadium, Rancangan Acak Kelompok

\begin{abstract}
Tenebrio molitor is an insect that has economic value and easily to rear. The proper feeding can increase the growth and reproduction of $T$. molitor. Yeast is the main food of the $T$. molitor that can enhance the process of digestion to achieve the optimal growth. While styrofoam is polistiren that could be used as an alternative for T. molitor food. The purpose of this research is to know the effect of two kinds of feed (yeast and styrofoam) to the longevity of $T$. molitor larvae. This research was laboratory experiments using Random Design Group with 10 replications. The parameters observed in the study were the length of larvae, larvae weight, longevity of larvae, and the weight of the food that consumed by the larvae. The colected data were analyzed by T-test. The results showed that food affects larvae weight, length, and the duration of larvae stage $(p<0.05)$. The larvae of $T$. molitor that was fed with yeast have shorter longevity than larvae was fed with styrofoam.
\end{abstract}

Key Words : Tenebrio molitor, yeast, styrofoam, stadium, Random Design Group 


\section{PENDAHULUAN}

Kumbang tepung atau Tenebrio molitor merupakan salah satu serangga yang termasuk dalam ordo Coleoptera. Akhir-akhir ini T. molitor sudah banyak dikembangkan karena mempunyai banyak manfaat, misalnya sebagai pakan ternak, sebagai bahan tambahan dalam makanan manusia, dan sebagai objek pengujian dalam penelitian. T. molitor digunakan sebagai pakan ternak dikarenakan terdapat kandungan nutrisi berupa lemak dan protein yang dapat berperan penting dalam proses pertumbuhan ternak. $T$. molitor digunakan sebagai bahan tambahan dalam makanan bagi manusia karena dipercaya dapat menyembuhkan beberapa macam penyakit seperti diabetes, darah tinggi, dan penyakit jantung. T. molitor digunakan sebagai objek pengujian dalam berbagai penelitian yang ada di Laboratorium (Setyolaksono, 2014), karena mudah dipelihara dan pakannya mudah didapat (Sitompul, 2006).

T. molitor biasa dibudidayakan dengan pakan ragi. Ragi bersifat katabolik atau memecah komponen yang kompleks menjadi zat yang lebih sederhana sehingga lebih mudah dicerna oleh $T$. molitor. Menurut Widodo (2011) penambahan ragi tape pada pakan dapat meningkatkan aktivitas pencernaan $T$. molitor sehingga pertumbuhannya menjadi optimal. Dalam beberapa hal pertumbuhan ragi dalam bahan pakan menyebabkan perubahan yang menguntungkan seperti perbaikan bahan pakan dari sisi mutu, baik dari aspek gizi maupun daya cerna serta meningkatkan daya simpannya. Selain itu penggunaan ragi juga sebagai sumber protein dan vitamin.
Styrofoam merupakan kemasan plastik yang sangat banyak penggunaannya untuk membungkus bahan pangan. Selain praktis dan mudah didapat bahannya pun ringan dan mudah dipegang. Karena banyaknya penggunaan styrofoam maka limbah akibat pemakaiannya juga semakin banyak, meskipun styrofoam sangat sulit untuk didaur ulang (BPOM RI, 2008).

Styrofoam memiliki bahan dasar polistiren. Polistiren merupakan bahan plastik yang sangat rapuh, kaku, ringan dan tembus cahaya. Karena kelemahannya tersebut polistiren lalu ditambahkan dengan bahan lain seperti senyawa butadien dan seng sehingga sifat jernih berubah menjadi putih susu. Agar polistiren lebih lentur maka ditambahkan zat plasticizer seperti butil hidroksi toluena dan DOP (dioktil ptalat) (Sulchan dan Endang, 2007).

Baru baru ini sudah dilakukan penelitian tentang styrofoam sebagai pakan serangga. Menurut Wu, dkk (2016) larva T. molitor mampu memakan styrofoam yang berbahan dasar polystyrene. Styrofoam yang diberikan sebanyak 5,8 g sebagai pakan 500 ekor T. molitor tersebut habis dalam waktu 1 bulan. Bakteri pada usus T. molitor mampu memecah bahan styrofoam tersebut dengan cepat.

Tujuan dari penelitian ini adalah untuk mengetahui pengaruh dua jenis pakan (ragi dan styrofoam) terhadap lama stadium larva kumbang Tenebrio molitor. Hasil penelitian ini diharapkan dapat memberikan pengetahuan bagi masyarakat untuk mendapatkan pakan alternatif dan membantu mengurangi limbah styrofoam yang dibuang ke lingkungan dengan memanfaatkan kumbang $T$. molitor 
31 / Rahmawati, Nukmal, N., Umar, S.

\section{Bahan dan Metode}

Penelitian ini dilakukan pada Bulan Juni- Agustus 2016 di Laboratorium Zoologi Jurusan Biologi Fakultas Matematika dan IImu Pengetahuan Alam Universitas Lampung. Rancangan yang digunakan dalam penelitian ini adalah Rancangan Acak Kelompok dengan 2 perlakuan terhadap 10 instar larva, yaitu pakan ragi dan pakan styrofoam. Setiap kelompok perlakuan dilakukan sebanyak 10 kali pengulangan.

Tahapan penelitian meliputi :

1. Tahap Persiapan

\section{a. Persiapan Hewan Uji}

Hewan uji yang digunakan dalam penelitian ini adalah larva Tenebrio molitor. Larva uji yang digunakan tersebut dibeli di pasar burung Tanjung Karang kemudian dilakukan pemisahan berdasarkan instarnya. Setiap instar larva lalu ditimbang berat awal dan panjang awal.

\section{b. Persiapan Wadah dan Pakan}

Disiapkan sebanyak 200 wadah, dibersihkan dan diberi kapas sebagai media pertumbuhan T. molitor. Wadah digunakan sebagai tempat larva $T$. molitor untuk berkembang. Pada penelitian ini digunakan 2 jenis pakan yaitu ragi dan styrofoam. Berat pakan yang akan diberikan adalah 1,2 mg dan diberikan per 3 hari. Setelah persiapan pakan dan wadah selesai maka larva $T$. molitor sebanyak 1 ekor dimasukkan ke dalam wadah yang telah terisi pakan.

\section{Tahap Pengamatan}

Parameter yang diamati berupa panjang larva, berat larva, lama stadium larva, dan berat pakan yang dikonsumsi. Pengamatan dan pengukuran dilakukan setiap 3 hari sekali dalam waktu sebulan.

\section{Analisis Data}

Data yang didapat selanjutnya dianalisis dengan menggunakan Uji T. Parameter yang diuji adalah berat larva, panjang larva, lama stadium larva, dan pakan yang dimakan serta dilakukan analisis korelasi antara pakan dengan berat dan panjang larva. Analisis data menggunakan program SPSS 17.

\section{Hasil}

A. Berat Larva

Hasil uji t. yang disajikan pada Tabel.1 menunjukkan bahwa terdapat perbedaan yang nyata pada rata-rata berat larva kumbang yang diberi pakan ragi dan larva kumbang yang diberi pakan styrofoam ( $p \leq$ $0,05)$.

Tabel 1. Perbandingan rata-rata berat setiap instar larva kumbang yang diberi pakan ragi dan pakan styrofoam

\begin{tabular}{ccccc}
\hline Instar & $\begin{array}{c}\text { Berat larva } \\
\text { diberi pakan } \\
\text { ragi }(\mathbf{m g} \pm \mathbf{s d})\end{array}$ & $\begin{array}{c}\text { Berat larva } \\
\text { diberi pakan } \\
\text { styrofoam } \\
\text { (mg } \pm \text { sd) }\end{array}$ & $\begin{array}{c}\text { Perbe- } \\
\text { daan } \\
\text { berat } \\
\text { (mg) }\end{array}$ & $\begin{array}{c}\text { Sig (2- } \\
\text { tailed) }\end{array}$ \\
\hline 1 & $12,50 \pm 1,17$ & $11,54 \pm 0,83$ & 0,96 & 0,01 \\
2 & $29,17 \pm 0,97$ & $27,78 \pm 1,66$ & 1,39 & 0,04 \\
3 & $38,82 \pm 1,07$ & $37,38 \pm 1,69$ & 1,44 & 0,05 \\
4 & $49,87 \pm 2,27$ & $48,31 \pm 1,82$ & 1,56 & 0,05 \\
5 & $60,80 \pm 1,44$ & $59,14 \pm 1,64$ & 1,66 & 0,04 \\
6 & $72,46 \pm 1,39$ & $70,84 \pm 1,69$ & 1,62 & 0,05 \\
7 & $92,63 \pm 2,02$ & $90,17 \pm 2,19$ & 2,45 & 0,03 \\
8 & $110,30 \pm 1,68$ & $108,03 \pm 2,76$ & 2,27 & 0,04 \\
9 & $131,80 \pm 3,18$ & $129,39 \pm 2,39$ & 2,41 & 0,04 \\
10 & $148,55 \pm 1,22$ & $146,94 \pm 2,35$ & 1,61 & 0,03
\end{tabular}

Keterangan : Nilai signifikansi $(p \leq 0,05)$ menyatakan bahwa ada perbedaan nyata pada perlakuan dengan uji t.

Larva kumbang yang diberi pakan ragi memiliki tubuh yang lebih berat dibandingkan larva kumbang yang diberi pakan styrofoam, untuk semua tingkatan instar (Tabel 1). 
B. Panjang Larva

Hasil uji t yang disajikan pada Tabel 2. menunjukkan bahwa terdapat perbedaan yang nyata antara rata-rata panjang larva kumbang yang diberi pakan ragi dengan larva kumbang yang diberi pakan styrofoam $(p \leq 0,05)$.

Tabel 2. Perbandingan rata-rata panjang setiap instar larva kumbang yang diberi pakan ragi dan larva kumbang yang diberi pakan styrofoam

\begin{tabular}{ccccc}
\hline Instar & $\begin{array}{c}\text { Panjang } \\
\text { larva diberi } \\
\text { pakan ragi } \\
(\mathbf{m m} \pm \mathbf{s d})\end{array}$ & $\begin{array}{c}\text { Panjang } \\
\text { larva diberi } \\
\text { pakan } \\
\text { styrofoam } \\
(\mathbf{m m} \pm \mathbf{s d})\end{array}$ & $\begin{array}{c}\text { Perbe- } \\
\text { daan } \\
\text { pan- } \\
\text { jang } \\
(\mathbf{m m})\end{array}$ & $\begin{array}{c}\text { Sig } \\
(\mathbf{2}- \\
\text { tail- } \\
\text { ed) }\end{array}$ \\
\hline 1 & $6,60 \pm 0,51$ & $6,20 \pm 0,42$ & 0,4 & 0,03 \\
2 & $9,60 \pm 0,51$ & $9,00 \pm 0,66$ & 0,6 & 0,02 \\
3 & $12,30 \pm 0,82$ & $11,70 \pm 0,82$ & 0,6 & 0,05 \\
4 & $15,00 \pm 0,81$ & $14,30 \pm 0,48$ & 0,7 & 0,02 \\
5 & $17,90 \pm 0,56$ & $17,30 \pm 0,48$ & 0,6 & 0,05 \\
6 & $19,90 \pm 0,56$ & $19,40 \pm 0,51$ & 0,5 & 0,01 \\
7 & $23,60 \pm 0,69$ & $22,60 \pm 0,69$ & 1,0 & 0,01 \\
8 & $26,10 \pm 0,56$ & $25.30 \pm 0,48$ & 0,8 & 0,02 \\
9 & $28,60 \pm 0,51$ & $28,20 \pm 0,42$ & 0,4 & 0,03 \\
10 & $30,70 \pm 0,48$ & $30,30 \pm 0,48$ & 0,4 & 0,03 \\
\hline
\end{tabular}

Keterangan : Nilai signifikansi $(p \leq 0,05)$ menyatakan bahwa ada perbedaan nyata pada perlakuan dengan uji $\mathrm{t}$

Larva kumbang yang diberi pakan ragi mempunyai tubuh lebih panjang dibanding dengan larva yang diberi pakan styrofoam untuk semua tingkatan instar (Tabel 2).

\section{Lama Stadium Larva}

Hasil uji t pada Tabel 3. menunjukkan bahwa terdapat perbedaan yang nyata antara ratarata lama stadium larva kumbang yang diberi pakan ragi dengan yang diberi pakan styrofoam $(p \leq 0,05)$.
Tabel 3. Perbandingan rata-rata lama stadiumlarva setiap instar kumbang yang diberi pakan ragi dan larva kumbang yang diberi pakan styrofoam

\begin{tabular}{ccccc}
\hline Instar & $\begin{array}{c}\text { Lama } \\
\text { stadium } \\
\text { larva yang } \\
\text { diberi } \\
\text { pakan ragi } \\
\text { (hari } \pm \text { sd) }\end{array}$ & $\begin{array}{c}\text { Lama } \\
\text { stadium } \\
\text { larva yang } \\
\text { diberi } \\
\text { pakan } \\
\text { styrofoam } \\
\text { (hari } \pm \text { sd) }\end{array}$ & $\begin{array}{c}\text { Perbe } \\
\text { daan } \\
\text { stadi- } \\
\text { um } \\
\text { larva } \\
\text { (hari) }\end{array}$ & $\begin{array}{c}\text { Sig (2- } \\
\text { tail- } \\
\text { ed) }\end{array}$ \\
\hline 1 & $3,03 \pm 0,04$ & $3,13 \pm 0,04$ & 0,10 & 0,000 \\
2 & $3,12 \pm 0,04$ & $3,19 \pm 0,07$ & 0,07 & 0,004 \\
3 & $3,15 \pm 0,05$ & $3,23 \pm 0,08$ & 0,08 & 0,001 \\
4 & $3,17 \pm 0,08$ & $3,21 \pm 0,09$ & 0,04 & 0,003 \\
5 & $3,19 \pm 0,07$ & $3,23 \pm 0,04$ & 0,04 & 0,003 \\
6 & $3,11 \pm 0,03$ & $3,28 \pm 0,04$ & 0,17 & 0,000 \\
7 & $3,12 \pm 0,07$ & $3,24 \pm 0,05$ & 0,12 & 0,005 \\
8 & $3,07 \pm 0,06$ & $3,26 \pm 0,08$ & 0,19 & 0,000 \\
9 & $3,32 \pm 0,10$ & $3,43 \pm 0,08$ & 0,11 & 0,004 \\
10 & $3,38 \pm 0,06$ & $3,57 \pm 0,04$ & 0,19 & 0,000 \\
\hline
\end{tabular}

Keterangan : Nilai signifikansi $(p \leq 0,05)$ menyatakan bahwa ada perbedaan nyata pada perlakuan dengan uji t.

Lama stadium larva kumbang yang diberi pakan ragi dan larva kumbang yang diberi pakan styrofoam menunjukkan bahwa pada larva kumbang pakan ragi lebih cepat mengalami pergantian instar dibanding pada larva kumbang yang diberi pakan styrofoam, untuk semua tingakatan instar (Tabel 3).

D. Pakan yang dimakan (Ragi dan Styrofoam) Hasil uji t pada Tabel 4. menunjukkan bahwa terdapat perbedaan yang nyata antara ratarata berat pakan ragi dan pakan styrofoam yang dimakan oleh larva kumbang ( $p \leq$ $0,05)$.

Larva kumbang lebih banyak memakan pakan ragi dibandingkan dengan pakan styrofoam, untuk semua tingkatan instar (Tabel 4). 
33 / Rahmawati, Nukmal, N., Umar, S.

Tabel 4. Perbandingan rata-rata berat pakan yang dimakan setiap instar larva kumbang

\begin{tabular}{ccccc}
\hline Instar & $\begin{array}{c}\text { Pakan ragi } \\
\text { yang } \\
\text { dimakan } \\
\text { larva (mg } \pm \\
\text { sd) }\end{array}$ & $\begin{array}{c}\text { Pakan } \\
\text { styrofoam } \\
\text { yang } \\
\text { dimakan } \\
\text { larva (mg } \pm \\
\text { sd) }\end{array}$ & $\begin{array}{c}\text { Perbe- } \\
\text { daan } \\
\text { pakan } \\
\text { (mg) }\end{array}$ & $\begin{array}{c}\text { Sig (2- } \\
\text { tailed) }\end{array}$ \\
\hline 1 & $0,32 \pm 0,05$ & $0,19 \pm 0,05$ & 0,13 & 0,000 \\
2 & $0,41 \pm 0,05$ & $0,25 \pm 0,05$ & 0,16 & 0,000 \\
3 & $0,49 \pm 0,05$ & $0,29 \pm 0,09$ & 0,20 & 0,000 \\
4 & $0,57 \pm 0,06$ & $0,33 \pm 0,12$ & 0,24 & 0,000 \\
5 & $0,66 \pm 0,06$ & $0,43 \pm 0,14$ & 0,23 & 0,000 \\
6 & $0,69 \pm 0,07$ & $0,51 \pm 0,08$ & 0,18 & 0,000 \\
7 & $0,78 \pm 0,09$ & $0,52 \pm 0,07$ & 0,26 & 0,000 \\
8 & $0,86 \pm 0,08$ & $0,54 \pm 0,06$ & 0,32 & 0,000 \\
9 & $0,98 \pm 0,07$ & $0,64 \pm 0,05$ & 0,34 & 0,000 \\
10 & $1,08 \pm 0,06$ & $0,81 \pm 0,05$ & 0,27 & 0,000
\end{tabular}

Keterangan : Nilai signifikansi $(p \leq 0,05)$ menyatakan bahwa ada perbedaan nyata pada perlakuan dengan uji t.

Hasil analisis korelasi antara panjang dan berat dengan larva dengan berat pakan yang dimakan menunjukkan hubungan korelasi positif untuk kedua jenis pakan (Gambar 1-4).

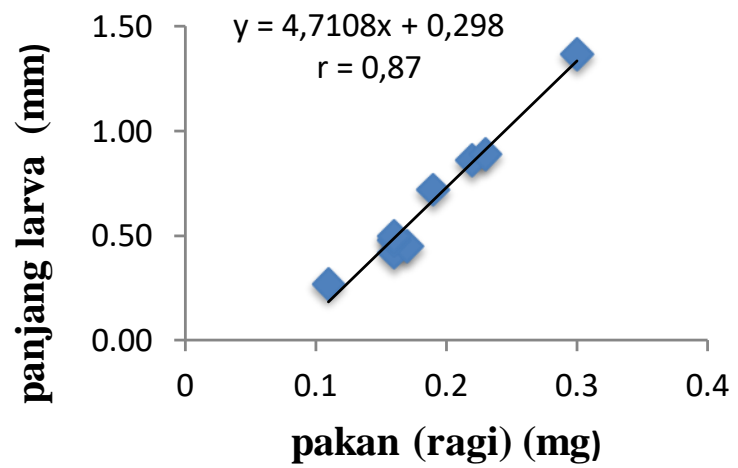

Gambar 1. Hubungan Korelasi panjang larva $T$. molitor dan pakan ragi

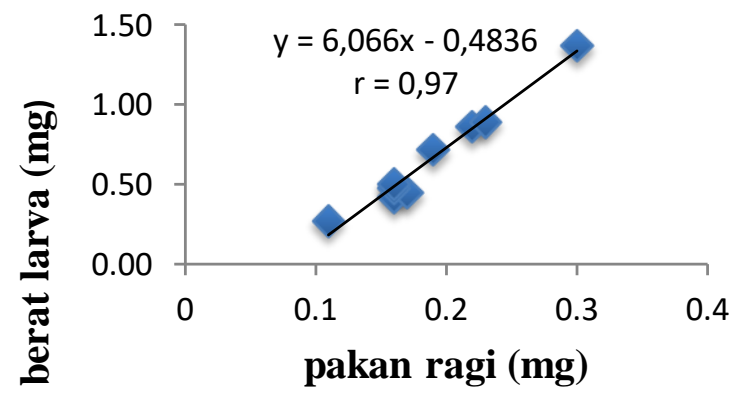

Gambar 2. Hubungan larva yang diberi pakan ragi dan berat larva

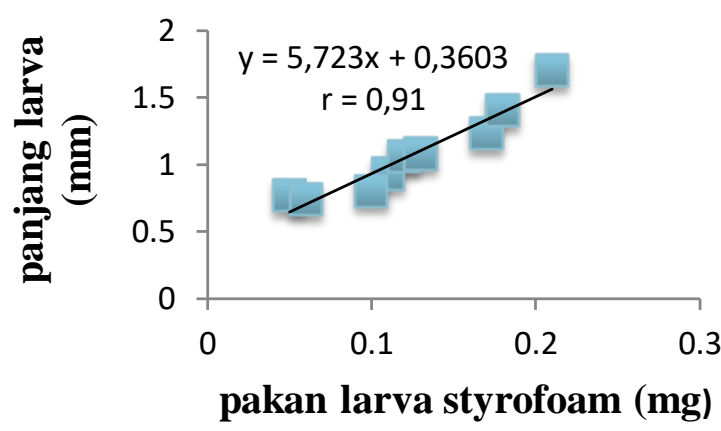

Gambar 3. Hubungan Korelasi panjang larva $T$. molitor dan pakan styrofoam

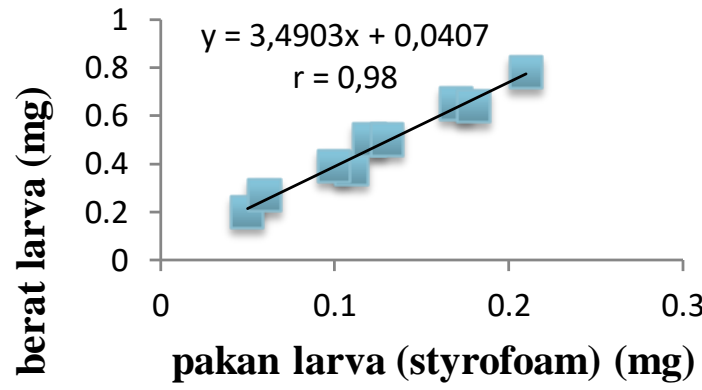

Gambar 4. Hubungan larva yang diberi pakan styrofoam dan berat larva

\section{Pembahasan}

Larva kumbang yang diberi pakan ragi dan styrofoam mengalami pertambahan berat dengan nilai perbedaannya dari $0,96 \mathrm{mg}-2,45 \mathrm{mg}$ keduanya tidak terlalu berpengaruh, hal ini sesuai dengan penelitian Yang, dkk (2015) yang menyatakan bahwa larva T. molitor yang diberi pakan styrofoam mengalami pertumbuhan yang tidak jauh berbeda dengan larva yang diberi pakan biasa.

Pada perbedaan berat larva dan perbedaan panjang di instar 1 paling rendah perbedaannya dengan nilai 0,96 mg karena pada instar awal ini masih sedikit memakan pakan sehingga bobot tubuh juga masih sedikit penambahannya. Sedangkan pada instar 7 mempunyai perbedaan yang paling tinggi dengan nilai $2,45 \mathrm{mg}$, baik pada 
berat dan panjang dikarenakan pada instar tersebut kebutuhan makan sangat banyak karena akan menunju ke fase pupa (tidak makan). Sehingga bobot tubuh pada instar 7 mengalami peningkatan yang tajam (Tabel 1.)

Lama stadium larva T. molitor yang diberi pakan ragi dan styrofoam mengalami pertambahan dengan perbedaan dari $0,04 \mathrm{mg}-0,19 \mathrm{mg}$ hal ini menunjukkan bahwa lama stadium larva yang diberi pakan ragi lebih cepat dibanding lama stadium pakan styrofoam (Dish, 2006).

Pada Tabel 3. menunjukkan bahwa perbedaan stadium larva pada instar 4 yang paling rendah yaitu $0,04 \mathrm{mg}$ sedangkan perbedaan yang paling tinggi adalah pada instar 8 dengan nilai $0,19 \mathrm{mg}$. Pada instar 4 memiliki perbedaan paling rendah karena pada instar ini larva masih memakan sedikit pakan sehingga lama stadium lebih lambat dua kali lipat dibanding pada instar 8 yang membutuhkan pakan yang banyak untuk menuju fase pupa sehingga pada fase instar 8 lebih cepat. Menurut Sitompul (2006) pakan yang diberikan dapat mempengaruhi perubahan pergantian instar larva kumbang T. molitor. Hasil pengaruh pakan terhadap stadium larva dapat dilihat pada Tabel 3.

Bobot badan kumbang T. molitor akan semakin tinggi jika larva mendapat pakan yang bernutrisi dan jumlah yang cukup. Tipe dan jumlah makanan yang dikonsumsi mempengaruhi pertumbuhan, perkembangan, reproduksi, tingkah laku dan berbagai sifat-sifat morfologi lain seperti ukuran dan warna tubuh (Borror et al, 1982).

Menurut Rosadi (2001) stadium larva merupakan stadium makan sehingga perkembangan pada stadium tersebut dipengaruhi oleh faktor komposisi dan kandungan pakan. Pakan yang kurang sesuai akan menyebabkan siklus hidup menjadi lebih panjang.

Perbedaan pakan antara ragi dan styrofoam yang paling rendah adalah pada instar 1 karena pada instar ini larva T. molitor masih sedikit sekali memakan pakan yang diberikan sehingga hasilnya rendah, sedangkan pada instar 8 memiliki perbedaan pakan paling tinggi karena di instar ini larva membutuhkan pakan yang banyak untuk dimakan untuk menuju fase pupa.

Larva kumbang T. molitor yang diberikan pakan dengan jumlah yang sama menunjukkan bahwa dengan pakan ragi lebih banyak dimakan oleh larva T. molitor sedangkan pada pakan styrofoam lebih sedikit yang dimakan. Perbedaan ini mungkin berhubungan dengan ketersediaan bakteri Exiguobacterium sp. di usus larva. Apabila ketersediaan bakteri banyak maka senyawa organik hidrokarbon pada styrofoam juga lebih banyak dapat diuraikan. Bakteri tersebut mampu menguraikan senyawa organik hidrokarbon seperti polistiren pada styrofoam lalu mengubahnya jadi biomassa terbatas yang dapat digunakan sebagai sumber energi bagi sintesis biomassa atau pertumbuhan (Yang et al. , 2015).

Dari hasil pengamatan pengaruh pakan terhadap panjang larva menunjukkan bahwa pada larva yang diberi ragi memiliki nilai koefisien korelasi dengan $r=0,87$ sedangkan pada larva yang diberi pakan styrofoam nilai koefisien korelasinya dengan $r=0,94$. Terdapat nya nilai korelasi yang positif walaupun lemah dapat diartikan bahwa dengan pemberian pakan baik ragi maupun styrofoam memberi pengaruh bagi panjang larva. Semakin banyak pemberian pakan maka panjang larva dihasilkan juga bertambah (Tabel 4 ). 
35 / Rahmawati, Nukmal, N., Umar, S.

Hasil pengamatan pengaruh pakan terhadap berat larva yang diberi pakan ragi menunjukkan hasil koefisien korelasi $r=0,97$. Sedangkan pada larva yang diberi pakan styrofoam menunjukkan hasil koefisien korelasi dengan $r=0,98$. Ini menunjukkan bahwa antara ragi dan styrofoam hasil korelasi tidak jauh berbeda karena hanya berbeda sedikit.

Hubungan antara berat larva yang diberi ragi dengan pakan ragi adalah positif yang berarti semakin banyak pakan maka berat larva akan semakin berat, inipun berlaku juga pada larva yang diberi pakan styrofoam. Nilai korelasi untuk hubungan antara pakan dan berat larva T. molitor baik yang diberi ragi dan styrofoam termasuk dalam korelasi yang cukup. Kedua nilai korelasi ini menunjukkan positif karena berpengaruh pada nilai berat di (Tabel 1.). Dari Tabel 1. tersebut menunjukkan adanya penambahan berat dari $\mathrm{T}$. molitor sehingga berpengaruh terhadap nilai korelasi.

\section{KESIMPULAN}

Kesimpulan yang didapat pada penelitian ini yaitu larva T. molitor yang diberi pakan ragi mengalami perubahan instar lebih cepat dibandingkan pada larva yang diberi pakan styrofoam.

\section{DAFTAR PUSTAKA}

BADAN POM RI. 2008. Polistirena Foam (Styrofoam).

Borror, D.J, C. A. Triplehorn dan N. F. Johnson. 1982. Pengenalan Pelajaran Serangga. Edisi ke-6. Terjemahan: Partosoedjono, S. Gadjah Mada University Press. Yogyakarta.

Direktorat Gizi Departemen Kesehatan RI. 1981. Daftar Komposisi Bahan Makanan. Bharatara Karya Aksara. Jakarta.
Dish, C. 2006. Superworms, Mealworms, and Giant Mealworms. Diakses : www.chameleonsdish.com/insects/worm diff.htm. Diunduh :11 Juli 2008

Setyolaksono, M.P. 2014. Tenebrio molitor Hama Pasca Panen yang Bermanfaat. [internet]. Diunduh pada (12 Februari 2016). Tersedia pada http://ditjenbun.pertanian.go.id/bbpptpa mbon/berita-309-tenebrio-molitor-hamapascapanen-yang-bermanfaat.html

Sihombing, D. T. H. 1999. Satwa Harapan I: Cacing Tanah, Bekicot, Keong, Kupukupu, Ulat Hongkong. Pengantar Ilmu dan Teknologi Budidaya. Pusaka Wirausaha Muda. Bogor.

Sitompul, R.S. 2006. Pertumbuhan Dan Konversi Pakan Ulat Tepung (Tenebrio molitor L.) Pada Kombinasi Pakan Komersial Dengan Dedak Padi, Onggok dan Pollard. IPB. Skripsi Penelitian.

Sulchan, M . dan N.W. Endang. 2007. Keamanan Pangan Kemasan Plastik dan Styrofoam. UNDIP. Semarang.

Widodo. 2011. Fermentasi Ragi Tape. [internet]. Diunduh pada( 23 Mei 2016). Tersedia pada http://far71. wordpress.com/2011/06/16/fermentasiragi-tape/.

Wu. W, Zhao. J, dan Yang, R. 2015. Biodegradation and Mineralization of Polystyrene by Plastic-Eating Mealworms: Part 1.Chemical and Physical Characterization and Isotopic Test. Environ. Sci. Technol., 2015, 49, 12080-12086. 